\title{
A NEW SPECIES OF EPIDENDRUM (ORCHIDACEAE) FROM PANAMA
}

\author{
Marta KolanowsKa \& Katarzyna MystKowsKa ${ }^{1}$
}

\begin{abstract}
A new species of Epidendrum is described and illustrated based on Panamanian material. The new entity belongs to the E. nocturnum complex and is distinguished by its oblong-elliptic leaves and by lip shape.
\end{abstract}

Key words: biodiversity, Darién, Epidendrum, Neotropics, Panama

Marta Kolanowska \& Katarzyna Mystkowska, Department of Plant Taxonomy and Nature Conservation, University of Gdańsk, Wita Stwosza 59, 80-308 Gdańsk, Poland; e-mail: kasiamyst@gmail.com

\section{INTRODUCTION}

The genus Epidendrum L., with ca 1500 species, is one of the largest taxa of this rank in Orchidaceae (e.g., Pinheiro \& Barros 2007; Pinheiro et al. 2009). While its representatives show a high level of morphological variation, the genus is recognized by the usually cane-like, simple or branching stem, distichous, conduplicate leaves, usually articulate, unilocular ovary, and lip usually ornamented with 2 basal globose calli, often with an additional pair of laminar calli ending in a narrow keel or a complex callus. The unique feature of the genus is fusion between the lip and gynostemium margins, forming the so-called cuniculus. The gynostemium may be slender to thick, elongate or short, erect or slightly arched, and the clinandrium abbreviated to longer than the anther. A column foot usually is absent. The anther is erect, subincumbent or incumbent, dorsiventrally flattened and ellipsoid to ovoid in outline. The connective is narrow, thin, and usually elongate towards the apex, forming a beak. Usually 4 pollinia are produced (Szlachetko \& Margońska 2002). The 3-ribbed capsule is ellipsoid, pyriform to subspherical.

Epidendrum species are found in various habitats including paramo, open areas of steep slopes, sand dunes, humid forest understorey, scrub and

\footnotetext{
1 Corresponding author
}

roadside vegetation (Pridgeon et al. 2005). Representatives of the genus are distributed from Argentina to North Carolina (USA).

The generitype of Epidendrum is E. nocturnum Jacq., which for a long time was treated as a variable species with a wide geographical range. Studies by Hágsater and collaborators (e.g., Hágsater \& Salazar 1993; Hágsater \& Soto 2003; Hágsater \& Sánchez Saldańa 2004, 2008, 2010) revealed, however, that a number of separated species should be recognized within the E. nocturnum complex. This group of species is often referred to as an informal group within Epidendrum. Currently $c a 30$ species are included in the $E$. nocturnum complex. They are easily distinguished from other representatives of the genus by their simple stems, short, racemose or pluri-racemose inflorescence lacking a spathaceous bract, and starshaped flowers with a 3-lobed lip.

Recent research on the orchid flora of the Darién Gap revealed a new species of Epidendrum in this region. The new entity belongs to the E. nocturnum complex. Previously only two species of this group, E. litense Hágsater \& Dodson and E. nocturnum Jacq., were reported from the study area; the occurrence of the latter was not confirmed during these studies. A key to their identification is given here. 


\section{DESCRIPTION OF THE NEW SPECIES}

Epidendrum dukei Kolan. \& Mystkowska, sp. nov.

Figs $1 \& 2$

Species similar in habit to E. portoricense Hágsater \& Ackerman, but with triangular-falcate lip lateral lobes forming $\mathrm{ca}$ 1/3 of lip length. The lip shape of this species resembles that of $E$. litense Hágsater \& Dodson but the leaves are much smaller and the petals are $c a 3$ times narrower than the sepals.

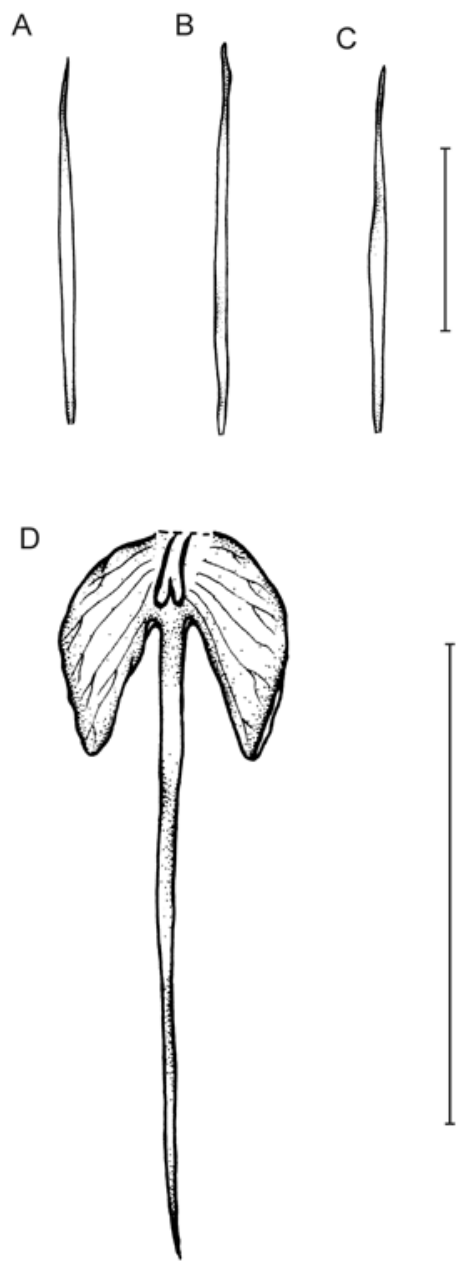

Fig. 1. Epidendrum dukei Kolan. \& Mystkowska, sp. nov. - dissected perianth. A - dorsal sepal, B - petal, C - lateral sepal, D - lip. Scale bars $=20 \mathrm{~mm}$. Drawn by N. Olędrzyńska from the holotype.

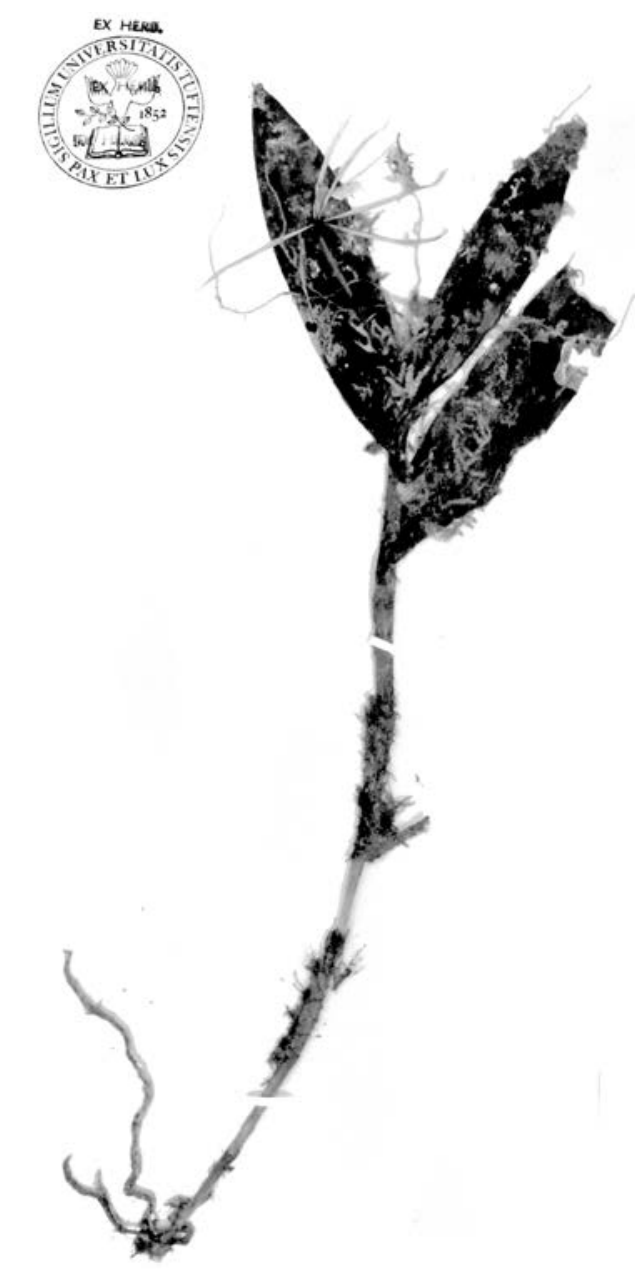

Fig. 2. Holotype of Epidendrum dukei Kolan. \& Mystkowska, sp. nov.

Holotype: PANAMA. Prov. Darién. Rio Balsa between Manene and Guayabo, 8 Nov. 1967, J. Duke \& N. Nickerson 14950 (MO).

Erect plant $\mathrm{ca} 45 \mathrm{~cm}$ tall. Roots basal, fleshy. Stem simple, cane-like, slightly laterally compressed. Leaves coriaceous, sheaths tubular; blade oblong-elliptic, obtuse, 9-11 cm long, 2.2-2.7 cm wide. Inflorescence apical, racemose, flowers open sequentially. Flower star-shaped, tepals greenishyellow, lip white. Floral bracts 8-10 mm long, triangular. Ovary $45 \mathrm{~mm}$ long, not inflated, smooth. Tepals similar, linear-lanceolate, subacute; dorsal sepal $38 \mathrm{~mm}$ long, $2 \mathrm{~mm}$ wide; petals $40 \mathrm{~mm}$ 
long, $1.5 \mathrm{~mm}$ wide; lateral sepals $40 \mathrm{~mm}$ long, $2 \mathrm{~mm}$ wide. Lip 3-lobed, $30 \mathrm{~mm}$ long, $9 \mathrm{~mm}$ wide across lateral lobes; lateral lobes $10 \mathrm{~mm}$ long, triangular-falcate, rounded; middle lobe $28 \mathrm{~mm}$ long, ensiform, acute; disc with two basal calli. Gynostemium $12 \mathrm{~mm}$ long, clinandrium hood erose-dentate.

ETYMology. Dedicated to James Duke, co-collector of the type specimen and author of several books about the flora of Darién.

Distribution And eCOlogy. Known exclusively from the Darién Gap, where it was found growing epiphytically in lowland. Flowering in November.

Notes. The new species undoubtedly belongs to the E. nocturnum complex based on its simple stem, racemose inflorescence, lack of a spathaceous bract, and star-shaped flowers. It is distinguishable from other representatives of the group by its oblong-elliptic leaves and triangular-falcate, rounded lip lateral lobes. In habit the species resembles E. portoricense Hágsater \& Ackerman and E. pseudonocturnum Hágsater \& Dodson. E. dukei differs in lip shape from both of them: in both species the lip lateral lobes form $c a 1 / 2$ of lip length. Also, they are semiovate in E. portoricense. The tepals of E. pseudonocturnum are $c a 10$ times longer than wide (vs 20 times longer in E. dukei). In lip shape $E$. dukei resembles $E$. litense, from which it is easily recognizable by its much larger leaves $(9-11 \times 2.2-2.7 \mathrm{~cm}$ vs $4-8 \times 0.7-0.9 \mathrm{~cm})$, subequally wide tepals (vs petals 3 times narrower than sepals) and linear-lanceolate petals (vs petals linear). Epidendrum cocornocturnum Hágsater differs from the new species by having semilanceolate lip lateral lobes and twice-larger flowers.

\section{KeY TO SPECIES OF THE EPIDENDRUM NOCTURNUM COMPLEX FROM THE DARIÉN GAP}

1. Leaves elliptic-ovate ...... E. nocturnum Jacq. 1 . Leaves narrowly elliptic-lanceolate to oblongelliptic ...................... 2
2. Leaves $c a 4-8 \times 0.7-0.9 \mathrm{~cm}$, petals $c a 3$ times narrower than sepals ................. ........... E. litense Hágsater \& Dodson

2. Leaves ca $9-11 \times 2.2-2.7 \mathrm{~cm}$, petals slightly narrower than sepals .................. ........ E. duckei Kolan. \& Mystkowska

ACKNOwLEDGMENTS. I thank the Curator and staff of the Missouri Botanical Garden herbarium (MO) for their kind hospitality and assistance during a visit, $\mathrm{Na}-$ talia Olędrzyńska for preparing the illustration, and the anonymous reviewers for valuable suggestions on the manuscript.

\section{REFERENCES}

Hágsater E. \& Sálazar G. A. (eds) 1993. Icones Orchidacearum 2. The genus Epidendrum, part 1. A century of new species in Epidendrum. Instituto Chinoín, Mexico.

Hágsater E. \& SÁNChez SAldańa L. (eds) 2004. Icones Orchidacearum 7. The genus Epidendrum, part 4 . A fourth century of new species in Epidendrum. Instituto Chinon, Mexico.

Hágsater E. \& SÁnchez SAldańa L. (eds) 2008. Icones Orchidacearum 11. The genus Epidendrum, part 7. Species new \& old in Epidendrum. Instituto Chinon, Mexico.

Hágsater E. \& SÁNChez SAldańa L. (eds) 2010. Icones Orchidacearum 13. The genus Epidendrum, part 9. Species new \& old in Epidendrum. Instituto Chinon, Mexico.

Hágsater E. \& Soto M. (eds) 2003. Icones Orchidacearum 5-6. Orchids of Mexico, parts 2-3. Instituto Chinon, Mexico.

Pinheiro F. \& Barros F. 2007. Epidendrum secundum Jacq. and E. denticulatum Barb. Rodr. (Orchidaceae): useful characters for their recognition. Hoehnea 34: 563-570.

Pinheiro F., Koehler S., Macędo Corręa A., Faria Salatino, M. L., Salatino A., Barros F. 2009. Phylogenetic relationships and infrageneric classification of Epidendrum subgenus Amphiglottium (Laeliinae, Orchidaceae). Plant Syst. Evol. 283: 165-177.

Pridgeon A. M., Cribb P. J., Chase M. A. \& Rasmussen F. (eds) 2005. Genera Orchidacearum. 4: Epidendroideae (Part 1). Oxford University Press, Oxford.

SzlachetKo D. L. \& MargońsKa H. B. 2002. Gynostemia Orchidalium II. Acta Bot. Fennica 173: 1-275. 